\title{
ARTIKKELIT
}

\section{У Ikääntyvien naisten kokema yksinäisyys}

\author{
Anne Rahikka ${ }^{1}$, Virpi Annaniemi ${ }^{1}$, Saini Suutari ${ }^{1}$
}

${ }^{1}$ Miina Sillanpään Säätiö

\begin{abstract}
Tässä artikkelissa tarkastellaan ikääntyvien 60-76-vuotiaiden naisten kokemaa yksinäisyyttä sekä heidän yksinäisyydelle antamiaan merkityksiä. Lisäksi artikkelin keskeisenä kysymyksenä on niukan toimeentulon vaikutukset yksinäisyyden kokemuksiin. Tutkimusaineisto koostuu yhdeksästä ikääntyvän naisen teemahaastattelusta, jotka suoritettiin pääkaupunkiseudulla kevään 2018 aikana. Analyysimenetelmänä käytettiin aineistolähtöistä sisällönanalyysiä.

Ikääntyvien naisten kokema yksinäisyys oli ajoittaista ja tilanteista,ja se nimettiin yksinäisyyden aaltomaiseksi vaihteluksi. Yksinäisyyden taustalla olivat elämäntilanteessa tapahtuneet muutokset. Nykyisistä sosiaalisista suhteista huolimatta naiset kaipasivat samanhenkistä seuraa. Olemassa oleva sosiaalinen verkosto ei pystynyt täyttämään heidän sosiaalisiin suhteisiin kohdistamiaan odotuksia. Niukka toimeentulo vahvisti naisten kokemaa yksinäisyyttä, koska se rajoitti vaihtoehtoisia keinoja ratkaista yksinäisyyttä. Niukkaan toimeentuloon yhdistyi lisäksi ulkopuolisuuden tunne, kun naiset joutuivat kieltäytymään heitä kiinnostavista harrastuksista ja tapahtumista. Yksinäisyyden kietoutuminen niukkaan toimeentuloon huolestutti suurinta osaa naisia ja elämänkulun janalla tulevaisuus näyttäytyi epävarmana. Yksinäisyys on yksilöllinen ja monimerkityksellinen ilmiö suhteessa aikaan ja elämäntilanteeseen. Yksinäisyyden ja taloudellisen toimeentulon välistä kytköstä tulisi selvittää lisää, jotta pystytään paremmin kehittämään toimivia interventioita yksinäisyyden ehkäisemiseksi.
\end{abstract}

\section{Johdanto}

Ikääntyneiden yksinäisyys on aihe, joka on kiinnostanut tutkijoita useiden vuosien ajan. Tutkimuksia ikääntyneiden yksinäisyydestä on julkaistu runsaasti muun muassa iäkkäiden yksinäisyyskokemuksista (Uotila 2011), yksinäisyydestä kotona asuvien iäkkäiden elämässä (Kangassalo \& Teeri 2017) ja yksinäisyyden suhteesta elämänkulkuun (Tiilikainen 2016). Lisäksi on esimerkiksi tutkittu sosiaalisten suhteiden ja terveyden välistä yhteyttä (Yang ym. 2016) ja sosiaalisen tuen merkitystä yksinäisyyden ja masentuneisuuden vähentämisessä ikääntyneillä (Liu, Gou \& Zuo 2016). Yksinäisyyden vähentämiseen tähtäävien interventioiden vaikutuksia on myös tarkasteltu useissa tutkimuksissa (Martina, Stevens \& Westerhof 2018; Savikko, Routasalo, Tilvis \& Pitkälä 2009; Honigh-de Vlaming, HavemanNies, Heinrich, Veer \& de Groot 2013).

Dahlbergin (2007) mukaan yksinäisyys on monille tuttua ja kyse on ilmiöstä, joka kuu- 
luu elämään. Yksinäisyyden kokemukset voivat vaihdella eri aikoina ja eri olosuhteissa. Yksinäisyydessä on kyse toisiin ihmisiin liittyvistä puutteellisista kytköksistä ja yhteyksistä. Sosiaalisten yhteyksien puuttumisen ohella yksinäisyyttä voi kokea myös toisten ihmisten ympäröimänä.

Ikääntyneiden kokeman yksinäisyyden on todettu olevan muuta väestöä yleisempää (Pinquart \& Sörensen 2001; Vaarama, Mukkila \& Hannikainen-Ingman 2014). Ikä ei ole ainoa yksinäisyyttä selittävä tekijä, vaan lisäksi elämänkulun mukanaan tuomat muutokset vaikuttavat yksinäisyyteen. Kumppanin menetys, vähentynyt sosiaalinen aktiivisuus, fyysisen toimintakyvyn rajoitteet, alakuloisuus sekä hyödyttömyyden kokemukset aiheuttavat yksinäisyyttä (Aartsen \& Jylhä 2011; Beal 2009; Dykstra \& van Tilburg \& de Jong Gierveld 2005; Tiilikainen 2016). Lisäksi on todettu, että yli 80-vuotiailla koettu terveydentila on yhteydessä yksinäisyyden kokemuksiin (Moisio \& Rämö 2007; Vaarama ym. 2014). Yksinäisyyteen vaikuttaa myös subjektiivinen arvio siitä, vastaavatko nykyiset ystävyyssuhteet niihin odotuksiin ja toiveisiin, joita ystävyydelle on asetettu (de Jong Gierveld \& van Tilburg 2010).

Peplau ja Perlman (1982) ovat koonneet yksinäisyyden määritelmiä ja kiteyttäneet niiden pohjalta yksinäisyyttä kuvaavat kolme piirrettä. Heidän mukaansa yksinäisyys on seurausta sosiaalisten suhteiden vähäisyydestä ja puutteellisista kytköksistä läheisiin, lähiyhteisöön tai laajemmin yhteiskuntaan. Yksinäisyyttä voidaan pitää myös subjektiivisena kokemuksena, mikä ei ole synonyymi sosiaaliselle eristyneisyydelle. Epämiellyttävyyden ja ahdistavuuden kokemukset ovat kolmas yksinäisyyteen liitetty piirre.

Yksinäisyyttä käsittelevissä tutkimuksissa viitataan usein Weissin (1985) määritelmään. Weiss (1985) jakaa yksinäisyyden emotionaaliseen ja sosiaaliseen yksinäisyyteen. Emotionaalinen yksinäisyys (loneliness of emotional isolation) on yksilön subjektiivinen reaktio läheisen ja kiintymystä tuottavan suhteen puuttu- miseen. Ikääntyneillä tärkeä ihmissuhde voi esimerkiksi kadota puolison kuoleman vuoksi. Emotionaalisen yksinäisyyden suurimpana riskitekijänä on puolison menetys, koska siihen liittyy läheisen kiintymyssuhteen menetys ja arjen rutiinien katoaminen (de Jong Gierveld \& van Tilburg 2010). Sosiaalinen yksinäisyys (loneliness of social isolation) sitä vastoin on sosiaalisen ryhmän ulkopuolelle jäämistä. Sosiaalinen yksinäisyys voi olla seurausta esimerkiksi työn menettämisestä, avioliiton päättymisestä tai asumisolosuhteiden muuttumisesta. Elämässä tapahtuneiden muutosten takia henkilö ei löydä sosiaalista yhteisöä, johon liittyä ja muutokset johtavat tyhjyyden tunteeseen sekä yksinäisyyteen. (Weiss 1985.)

Naisten ja miesten kokemaa yksinäisyyttä ja sen eroja on käsitelty useissa tutkimuksissa. Tulokset osoittavat, että naiset kokevat miehiä enemmän yksinäisyyttä (Beal 2009; Borys \& Perlman 1985; Pinquart \& Sörensen 2001). Dahlbergin ja McKeen (2014) mukaan naisten kokema yksinäisyys on miehiä useammin emotionaalista yksinäisyyttä. Naiset näyttäisivät kokevan miehiä vähemmän sosiaalista yksinäisyyttä (de Jong Gierveld \& van Tilburg 2010). Tätä on selitetty sillä, että naiset omaavat enemmän sosiaalista toimintakykyä aloitteelliseen sosiaalisten suhteiden luomiseen. Sosiaalisen yksinäisyyden osalta myös aikuisilla lapsilla on todettu olevan suuri merkitys. He voivat toimia ikääntyvän tukena ja kuuntelijana sekä etsiä keinoja, joilla yksinäisyyttä voidaan lievittää. (de Jong Gierveld \& van Tilburg 2010.) Aartsen ja Jylhä (2011) selittävät naisten ja miesten välistä eroa naisten suuremmalla altistumisella riskitekijöille. Elämänkulun muutokset, kuten naisten suurempi riski jäädä leskeksi on erityisesti tekijä, joka kasvattaa yksinäisyyden riskiä. Lisäksi naisten on miehiä helpompi puhua sosiaalisesti ei-hyväksyttävistä tunteistaan (Pinquart \& Sörensen 2001) ja kertoa avoimesti myös yksinäisyyden kokemuksistaan.

Naiset tai miehet eivät kuitenkaan muodosta yhtenäistä toisistaan eroavaa ryhmää (Ojala 
2010). Elämänkulun muutokset muokkaavat yksilöllistä kokemusmaailmaa. Tiilikainen (2016) korostaa, että yksinäisyys on subjektiivinen kokemus, joka on sekä prosessuaalista että suhteisiin sidottua. Yksinäisyyttä koetaan aina suhteessa johonkin: lähisuhteisiin, ympäröiviin yhteisöihin tai laajemmin yhteiskuntaan.

Yksinäisyys on moniulotteinen ilmiö, jota tässä tutkimuksessa tarkastellaan ikääntyvien naisten omista lähtökohdista, heidän itsensä kuvaamana. Yksinäisyys ei kiinnity vain ihmissuhteisiin, vaan kyse on laajemmin osallistumisen mahdollisuuksista ja yhteisöjen tarjoamasta osallisuudesta. Tutkimus täydentää aikaisempaa tutkimustietoa tarkastelemalla pienituloisten ikääntyvien naisten kokemaa yksinäisyyttä. Tutkimuksen tehtävänä on syventää ymmärrystä siitä, miten elämänkulun ja sosiaalisten suhteiden muutokset kietoutuvat yhteen pienituloisuuden kanssa tuottaen yksinäisyyden kokemuksia.Tutkimuskysymykset ovat seuraavat: Miten ikääntyvät naiset kuvaavat kokemaansa yksinäisyyttä? Miten pienituloisuus vaikuttaa yksinäisyyden kokemuksiin? Artikkelin lopussa pohditaan ehkäisevien interventioiden mahdollisuuksia ja sitä, miten ikääntyvien naisten osallisuutta voitaisiin edistää.

\section{Ikääntyvien toimeentulovaikeudet ja hyvinvoinnin aineettomat lähteet}

Ikääntyneiden yksinäisyyttä käsittelevissä tutkimuksissa yksinäisyyden on todettu liittyvän yksin asumiseen, asumiseen hoitokodissa, alhaiseen koulutukseen sekä pieniin tuloihin (de Jong Gierveld \& van Tilburg 2010). Pienituloisuus kytkeytyy myös alhaiseen itsetuntoon, mikä omalta osaltaan ehkäisee uusien sosiaalisten suhteiden syntymistä (Pinquart \& Sörensen 2011).

Eläketurvakeskuksen (Ahonen, Palomäki \& Polvinen 2017) laaja kyselytutkimus osoittaa, että vajaa puolet tutkimukseen osallistuneista eläkeläisistä (45 \%) koki vaikeuksia (pieniä vaikeuksia, vaikeuksia, suuria vaikeuksia) tavanomaisten menojen kattamisessa. Lisäksi puolella (52\%) oli vaikeuksia kattaa välttämättömiksi katsottavia menoja (ruoka, asuminen, lääkkeet, terveydenhoito, kulkeminen ja tietoliikenne). Edelleen puolet eläkeläisistä (53 \%) ilmoitti joutuneensa tinkimään rahan puutteen vuoksi kulutuksestaan. Kolmasosa (33 \%) kertoi, ettei heille jäänyt rahaa välttämättömyysmenojen jälkeen. (Ahonen ym. 2017.) Liukon ja Mustosen (2019) tutkimuksessa eläkeläisten koettua toimeentuloa vaikeuttavina tekijöinä mainittiin tulojen riittämättömyys, asumiskulujen kattamisen vaikeus ja huoli kulujen noususta ja eläkkeen ostovoimasta. Terveysja lääkekulut olivat menoja, joista eläkeläiset olivat useimmiten joutuneet karsimaan. Myös Hannikainen (2019) toteaa, että pienituloiset jättävät suurituloisia useammin käymättä lääkärissä rahan puutteen vuoksi. Miesten ja naisten välinen eläkevertailu osoittaa, että miesten työeläkkeet ovat keskimäärin naisten työeläkkeitä korkeampia. Miesten suuremmat työeläkkeet selittyvät pidemmillä työurilla sekä naisia korkeammalla palkkatasolla. (Nyman, Karjalainen \& Pösö 2018.)

Hyvinvoinnin lähteet muodostuvat sekä aineellisista tekijöistä, kuten kohtuullisesta toimeentulosta että aineettomista lähteistä, kuten yhteenkuuluvuudesta (Nussbaum 2011). Eräänä yksilön hyvinvointiin vaikuttavana tekijänä on se, kuinka paljon hän voi tehdä niitä asioita, jotka ovat hänelle tärkeitä (Hirvilammi 2015). Pienituloisilla säästäväinen elämäntapa voi olla taloudellista hyvinvointia helpottava tekijä, mutta pakonomainen menojen karsiminen on myös koettua hyvinvointia heikentävä tekijä (Liukko \& Mustonen 2019). Nussbaum (2011) toteaa, että ei riitä, että ihmiset omaavat toimintamahdollisuuksia, vaan sen ohella heillä tulee olla myös varmuus tulevasta. Pienituloisilla eläkeläisillä rahat saattavat riittää välttämättömiin perusmenoihin, mutta tulevaisuus näyttäytyy epävarmana, kun on jatkuva huoli eläkkeen riittämisestä (Liukko \& Mustonen 2019). Sosiaaliset suhteet ja kontaktit muodostavat tärkeän resurssin, joista voi 
saada tukea ja apua vastoinkäymisten, sairauksien tai yksinäisyyden kohdatessa (Thernborn 2014). Kun rahaa on vähän, elämä lukittuu ja sosiaaliset suhteet vähenevät (Isola ym. 2017). Niukka taloudellinen tilanne yhdistyneenä vähäisiin sosiaalisiin suhteisiin kuluttaa mentaalista energiaa, jota tarvitaan arjessa selviytymiseen (Mullainathan \& Shafir 2013). Toimeentulovaikeuksien keskellä ihminen kokee voimattomuutta ja näköalattomuutta, mikä heijastuu myös sosiaalisiin suhteisiin.

\section{Aineisto ja menetelmät}

Tutkimusaineisto kerättiin haastattelemalla yhdeksää pääkaupunkiseudulla asuvaa 60 76-vuotiasta naista. Kukaan haastateltava ei ollut enää työelämässä. Kahdeksan oli eläkkeellä ja yksi haastateltava oli työttömänä. Kaikilla oli lapsia, jotka yhtä lukuun ottamatta eivät asuneet enää kotona. Valtaosa, kuusi henkilöä, asui yhden hengen taloudessa ja kolme yhdessä joko puolison tai lapsensa kanssa. Haastateltavia yhdisti se, että he kaikki olivat osallistuneet omalla asuinalueellaan toteutettuun ikääntyville pienituloisille naisille tarkoitettuun ryhmätoimintaan. Ryhmään osallistumisen kriteereinä olivat koettu yksinäisyys ja pienituloisuus. Pienituloisuus ei ollut sidoksissa ennalta määriteltyyn tulotasoon vaan osallistujien omiin toimeentulokokemuksiin.

Teemahaastattelut toteutettiin maaliskuussa 2018. Haastattelut olivat yksilöhaastatteluita ja haastateltavien toiveiden mukaisesti haastattelupaikka oli joko haastateltavan koti, kaupungin kirjasto, kahvila tai toimistotilat. Haastattelujen ilmapiiri pyrittiin saamaan mahdollisimman turvalliseksi ja luottamukselliseksi. Haastattelun yhteydessä haastateltavat allekirjoittivat kirjallisen suostumuksen tutkimukseen osallistumisesta. Analyysivaiheessa aineisto anonymisoitiin, joten haastateltavat eivät tässä artikkelissa esiinny oikeilla nimillään.

Haastattelut toteutettiin teemahaastatteluina, joissa edettiin etukäteen valittujen teemo- jen ja niihin liittyvien tarkentavien kysymysten varassa (Hirsjärvi \& Hurme 2008; Tuomi \& Sarajärvi 2018). Haastatteluteemoja muodostettaessa hyödynnettiin ryhmätoiminnassa tehtyä alkukyselyä, jossa oli kartoitettu osallistujien kokemuksia yksinäisyydestä. Haastattelun alussa haastateltavia pyydettiin kuvailemaan sen hetkistä elämäntilannettaan ja kertomaan itsestään, kuten asumismuodosta, työhistoriasta ja terveydentilasta. Tämän jälkeen haastatteluissa keskityttiin yksinäisyyteen, jota kartoitettiin seuraavilla alateemoilla: yksinäisyyden kokemukset, yksinäisyyden syyt ja seuraukset, yksinäisyyden lievittämisen keinot sekä lisäksi kysyttiin haastattelun aikaisista sosiaalisista suhteista. Lopuksi haastattelussa kysyttiin vielä haastateltavan taloudellisesta tilanteesta. Haastateltavia pyydettiin kertomaan toimeentulostaan ja rahojen riittävyydestä. Toimeentulon riittävyys perustui tässä yhteydessä naisten omiin kokemuksiin. Haastateltavat olivat osallistuneet vertaisryhmään, jossa kaikkia yhdisti sama kokemus yksinäisyydestä. Ryhmässä he olivat jo tottuneet käsittelemään ja puhumaan kokemastaan yksinäisyydestä.

Haastatteluaineistoa kertyi yli 10 tuntia (610 minuuttia) ja keskimääräinen haastattelun kesto oli noin 70 minuuttia. Haastattelujen vaihteluväli oli 38 minuutista 118 minuuttiin. Haastatteluista kertyi aineistoa yhteensä 127 sivua. Keskimääräinen haastattelu oli litteroituna noin 14 sivua. Kokonaisuutena haastatteluaineisto on rikas, ja siitä on tähän artikkeliin valikoitunut vain pieni osa. Osalle naisista haastattelija oli tuttu jo pienituloisten naisten ryhmästä, jonka ohjaajana hän toimi. Tämä on tekijä, joka saattoi osaltaan madaltaa kynnystä kertoa avoimesti omista yksinäisyyden kokemuksista.

Aineiston analyysimenetelmänä käytettiin sisällönanalyysiä, jonka tavoitteena oli tuottaa tietoa ja uusia näkökulmia tutkimuksen kohteena olevasta ilmiöstä (Krippendorff 1990). Kyseessä oli aineistolähtöinen analyysi, jossa yksinäisyydestä pyrittiin luomaan tiivis kuvaus 
ja kytkemään tulokset aihetta koskeviin aikaisempiin tutkimuksiin. Analyysiyksikkönä olivat yksinäisyyttä ja taloudellista toimeentuloa koskevat lausumat (ks. Ruusuvuori, Nikander \& Hyvärinen 2010).

Haastatteluiden yhteydessä haastateltavien kanssa laadittiin verkostokartta heidän sosiaalisista suhteistaan. Haastattelija esitteli verkostokartan laatimisen periaatteet ja haastateltavalta kysyttiin, haluaako hän laatia kartan itsenäisesti vai yhdessä haastattelijan kanssa. Pääsääntöisesti meneteltiin siten, että haastattelija laati kartan haastattelutilanteessa yhteisen keskustelun pohjalta. Verkostokartan keskelle merkittiin haastateltava ja kartta koostui seuraavista lohkoista: perhe ja sukulaiset, ystävät, muut läheiset ihmiset, naapurit ja työkaverit sekä ammattilaiset. Lohkoihin merkittiin itselle tärkeät henkilöt. (Ks. Seikkula 1994.) Haastattelussa verkostokartan avulla kuvattiin ihmissuhteiden kokonaisuutta. Verkostokartta oli yhteinen keskustelun väline, jonka avulla hahmotettiin ihmissuhdeverkostoa. Aineiston analyysivaiheessa verkostokarttoja hyödynnettiin täydentävänä aineistona ja ne kuvasivat haastateltavien verkostojen laajuutta.

\section{Keskeiset tulokset}

Kukaan haastatteluihin osallistuneista naisista ei haastatteluhetkellä ollut työelämässä ja heitä yhdisti melko samanlainen taloudellinen tilanne. Tätä taustaa vasten on mahdollista tarkastella niitä merkityksiä, joita yksinäisyyteen ja taloudellisen toimeentulon niukkuuteen liitettiin. Aineiston teemoittelu tuotti kolme pääteemaa: elämänkulun muutokset, murentuvat sosiaaliset suhteet ja hauraan osallisuuden.

\section{Elämänkulun muutokset}

Haastateltavat kertoivat elämässä tapahtuneiden muutosten vaikutuksista kokemaansa yksinäisyyteen. Merkittävä muutos oli eläkkeelle jääminen. Kun työelämä päättyi, hiipuivat myös ystävyyssuhteet työkavereihin. Työelämä antoi yhteisen viitekehyksen ja työyhteisön jäsenet jakoivat saman arkitodellisuuden. Kun tämä yhteinen arki mureni, ei yhdistäviä tekijöitä enää ollut. Seuraavassa katkelmassa Inkeri kertoo, miten eläkkeelle jääminen vaikutti hänen sosiaalisiin suhteisiinsa.
Inkeri: No sanotaan, et siiben se pabiten, ku mä jäin työelämästä veke, ja sit ne työkaverit jäi sinne. Ja sit huomas et ne on iltasin väsy- neitä tai jos sovittiin et näbdään, "ku emmä millää jaksa”. Se biipu siihen.

Kaikki haastateltavat olivat haastatteluhetkellä eläkkeellä tai työelämän ulkopuolella. Heillä ei ollut työelämän tuomaa arjen rakennetta, vaan päivät olivat rytmiltään samanlaisia. Viikonpäivillä ei tuntunut enää olevan merkitystä, koska kaupatkin ovat viikonloppuna auki, joten viikonloput eivät siinä suhteessa eroa arkipäivistä.

Kaisa: No, mä siis oikeestaan - nyt on kyl pakko sanoo - niin että, ku ei oo minkään näköses työelämäs enää, niin välil päivät on ihan samat. Et sä et edes tiedä, mikä päivä on menossa.

Haastateltavat vertasivat eläkeläisen arkea aikaisempaan työssäoloaikaan, jolloin päivisin oltiin töissä ja illat kuluivat töistä toipuessa ja kotitöissä. Eräs haastateltava kuvasi työssäoloaikaa "selviytymisen aikana", johon liittyi päivien täyttyminen työn ja perhe-elämän velvoitteista. Vastakohtana aikaisemmalle kiireiselle arjelle, eläkeläisen arki tuntui tyhjältä ja yksitoikkoiselta. Karisto ja Tiilikainen (2017) kuvaavat yksinäisen aikamaisemaa autiona tasankona, josta ei löydy omaa paikannusta helpottavia maamerkkejä. Kun yksinäisyyttä peilataan elettyyn elämään, tuntuu yksinäisinä hetkinä aika kuluvan hitaasti ja päivät ovat samanlaisia. Elämä koetaan jäsentymättömänä, harmaana ja yksitoikkoisena.

Ilmi kertoo vaikutuksista, joita toiselle paikkakunnalle tapahtunut muutto aiheutti. 
Uusia ystäviä tai tuttavia uudelta kotipaikkakunnalta oli haastava löytää. Luontevia kohtaamisia uusien ihmisten kanssa ei syntynyt. Ilmi oli muuttanut monta kertaa ja lopulta muutto sekä samanaikainen työelämästä poisjäänti havahduttivat huomaamaan oman yksinäisyyden. Ilmin elämässä kahden tekijän yhtäaikainen vaikutus sai hänet huomaamaan tilanteen vakavuuden.

Ilmi: Mä oon elämäni aikana muuttanu monta kertaa ja aina on ystäväpiiri vaibtunu - ja sitte ku jäi eläkkeelle, niin buomas, että ei oikeestaan oo enää ketään, viimenenki muutti pois sitte, ettei oo tässä lähipiirissä.

Kun ystäväpiiri jää toiselle paikkakunnalle, niin tapaamisten järjestäminen on vaikeaa. Monet puhuivat pitkistä välimatkoista, jotka hankaloittivat sosiaalisten suhteiden ylläpitoa. Tapaamisia on vaikea järjestää, jos ei ole rahaa matkakustannusten kattamiseen. Pienillä tuloilla elävä eläkeläinen joutuu karsimaan kaikista ylimääräisistä menoista, jotta saa rahat riittämään välttämättömiin kuluihin (Liukko \& Mustonen 2019). Kyse voi olla ulkopuolisen silmin mitättömän pienistä summista, mutta henkilölle itselleen niiden merkitys on suuri. Matkakustannukset vaikeuttivat omalta osaltaan sosiaalisten suhteiden ylläpitoa ja rajoittivat ystävien tapaamisia.

Yksinäisyyteen voi havahtua esimerkiksi pitkän parisuhteen päättyessä, kun tärkeä ihmissuhde katoaa elämästä (Aartsen \& Jylhä 2011; Dykstra ym. 2005; Tiilikainen 2016). Alla olevassa katkelmassa Sirkka kuvaa kokemaansa yksinäisyyttä miehensä kuoleman jälkeen.

Sirkka: varsinkin sillo miehen kuoleman jälkeen koki kaubeestikkin sitä yksinäisyyttä, vaikka on siskot ja vaikka on muita, mut heillä on tietysti kaikilla oma elämä .... et kylläbän sitä kaipais sellasta juttukaverii, joka jakais sitä arkee. Ku se on se, että kaikki ympärillä olevat ibmiset on ihan ok ja niibin sä voit tukeutuu, mut ne ei jaa sitä arkee sun kanssa. Ja se on myös ehkä se, joka on vaikee sellasen ymmärtää, joka ei oo jääny vielä yksin.

Sirkalle miehen kuoleman jälkeinen aika oli emotionaalisesti vaikeaa. Vaikka hänellä on lapsia, lapsenlapsia ja sukulaisia, niin siitä huolimatta Sirkka koki, että läheiset eivät korvanneet menetystä, jonka aviomiehen kuolema aiheutti. Sirkka menetti läheisen ihmisen, jonka kanssa hän oli jakanut arjen. Puolison ja arjen rutiinien menetys ilmeni emotionaalisena yksinäisyytenä (Weiss 1984). Jos yksinäisyys määritellään perheen ja ystävien puuttumisena, ei Sirkka tämän määritelmän mukaan ole yksinäinen. Ystäväpiiri ei kuitenkaan pysty korvaamaan puolison menetystä. Usea haastateltava totesi, että ystäväpiirin elämäntilanteiden erilaisuus vaikeutti sosiaalisten suhteiden ylläpitoa. Lapsilla oli kiireinen elämä, entisillä työkavereilla työkiireet ja ystävillä saattoi olla läheisten hoitoon liittyviä velvoitteita.

Aino: Mut sit on niit, et se menee vähän näin, et on sit niitä aikoja, jollon tuntuu jotenkin huonommalta, et se on vähän tämmönen aaltoliike.

Yksinäisyys ei haastatelluilla naisilla ole välttämättä kroonista tai jatkuvaa, vaan se on pikemminkin ajoittaista aaltoliikettä, kuten Aino aineistokatkelmassa toteaa. Yksinäisyys ei ole pysyvä olotila, vaan siinä tapahtuu ajallista variaatiota (Russell, Peplau \& Cutrona 1980). Myös pitkittäistutkimuksissa on havaittu, että yksinäisyyden kokemuksiin liittyy ajallista vaihtelua (Tiilikainen 2016; Victor \& Bowling 2011). Vaihtelu kytkeytyy elämässä tapahtuviin negatiivisiin tai positiivisiin muutoksiin.

\section{Murentuvat sosiaaliset suhteet}

Haastattelujen yhteydessä laadittujen verkostokarttojen tarkastelu osoitti, että yhtä henkilöä lukuun ottamatta, kaikilla haastateltavilla oli melko laaja sosiaalinen verkosto. Verkostot 
muodostuivat perheestä, sukulaisista, ystävistä sekä muista läheisistä ihmisistä ja naapureista. Mainintoja ammattilaisista löytyi kahdelta haastateltavalta. Naisten verkosto painottui ensisijaisesti perheeseen ja sukulaisiin sekä ystäviin. Verkostokartoissa ystävien määrä vaihteli 5-9 ystävän välillä. Pitkien välimatkojen takia monille ystävien tapaaminen oli kuitenkin vaikeaa. Verkostokartoissa kuvattujen ystävien ja sukulaisten määrä kertoo verkoston laajuudesta. Verkostokartat eivät kuitenkaan kerro haastateltavien tyytyväisyydestä sosiaaliseen verkostoonsa ja siitä, missä määrin verkosto vastasi heidän toiveitaan ja odotuksiaan. Tätä seikkaa kysyttiin haastatteluissa erikseen verkostokartan laatimisen jälkeen. Kahdeksan haastateltavaa yhdeksästä vastasi, että on joko tyytyväinen tai periaatteessa tyytyväinen ystävien määrään. Toiveet ja odotukset liittyivät sen sijaan ystävyyden laadullisiin seikkoihin, kuten Aino asian seuraavassa katkelmassa määrittelee.

Aino: Varmaan ebkä joku semmonen sisältöasia. Ehkä mä kaipaisin enempi sitä tekemistä, jotain semmosta.

Haastatteluissa yksinäisyys näyttäytyi sosiaalisena yksinäisyytenä (Weiss 1985), johon toivottiin ratkaisua. Vaikka useimmilla naisilla oli melko laaja sosiaalinen verkosto, se ei kyennyt vastaamaan heidän toiveisiinsa. Olemassa olevilla ystävillä ja lapsilla sekä heidän perheillään oli omat kiireiset rutiininsa, joihin ei tohdittu tunkeutua tai se vaati liiallista sovittelua aikatauluihin. Vaikka yhteydet lapsiin olivat hyvät, kokivat naiset, että he eivät halunneet vaivata lapsia omilla asioillaan ja huolillaan, koska läheisillä oli oma kiireinen arkensa. De Jong Gierveld ja van Tilburg (2010) toteavat, että aikuiset lapset saattavat tiedostaa yksinäisyyden riskitekijät omien vanhempiensa kohdalla ja ottaa kuuntelijan ja tukijan roolin suhteessa ikääntyvään vanhempaan. Tässä aineistossa lasten merkitys tuen antajana ja kuuntelijana ei naisten puheessa ilmene merkittävänä yksinäisyyttä lieventävänä tekijänä. Syynä tähän saattaa olla se, että naiset eivät ehkä olleet puhuneet läheisilleen kokemastaan yksinäisyydestä, koska he eivät halunneet huolestuttaa läheisiään.

Sylvi kertoo, että jos ei ole moneen päivään vaihtanut sanaakaan kenenkään kanssa, puhuu hän vaikka koiranulkoiluttajalle. Sylvi pyrkii ratkaisemaan yksinäisyyttä sosiaalisen aktiivisuuden avulla, kuten aikaisemmissa tutkimuksissa on todettu (de Jong Gierveld ja van Tilburg 2010). Henkilökohtaiset valinnat vaikuttavat sosiaaliseen toimintakykyyn ja vuorovaikutussuhteisiin joko rajaavasti tai rikastuttavasti (Heikkinen 2013). Sylvi ratkoi puhumattomuutta ottamalla kontaktia täysin vieraiden ihmisten kanssa.
Sylvi: No, ei moneen päivään oo kukaan, mä voin olla monta päivää täällä kuule, ettei pu- helinkaan soi ja sit voi olla et kaikki soittaa sa- mana päivänä. Ja sit on monta päivää kuule, et mä en oo suutani aukassu kolmeen-neljään päivään. Mä en oo pubunu sanaakaan kenen- kään kanssa. Muuta kun kaupassa, et kiitos. Vaikka sä menet tonne, mut eibän siellä ku- kaan pubu, mut mä olen niin höppänäks tullu, et aina kun tulee joku koirankin kanssa, niin minä rupeen pubumaan höpöjä.

Aineistosta kuvastuu, miten omaa paikkaa ystävyyssuhteiden kentässä ei ole iän karttuessa helppo löytää. Haastateltavat pohtivat toisten tapaa toimia ja toiminnan aiheuttamia vaikutuksia. Monet kokivat yrittäneensä rakentaa uusia sosiaalisia suhteita, mutta se ei ollut mutkatonta, vaan tuotti heille pettymyksiä. Hankaluuksia rakentaa ystävyyssuhteita selitettiin sillä, että vastavuoroisuus puuttui. Voimavarat eivät riittäneet siihen, että aktiivisuus sosiaalisesta kanssakäymisestä oli vain omilla harteilla. Tuttuja kutsuttiin käymään ja toivottiin, että vastavuoroisuuden periaatteella omalle kohdalle osuisi vastakutsu. Mutta kun näin ei käynyt, synnytti tämä pettymyksen tunteita ja turhautumista. Sylvi kertoo esimerkin siitä, kuinka hänen yrityksensä löytää uusia 
ystäviä oli päättynyt tuloksettomana ja nostanut pintaa kysymyksiä siitä, miksi ihmiset toimivat näin. Yksinäisyys tekee arkanahkaiseksi. Ulkopuolisesta merkityksettömältä näyttävät mutta itselle voimakkaat kokemukset lävistävät mielen kuin tuskaa tuottavat nuolet. (Karisto \& Tiilikainen 2017.) Yhteydenpitoon liittyvät pettymykset ovat Kariston ja Tiilikaisen (2017) mukaan tällaisia tuskaa tuottavia kokemuksia.

Sylvi: Kukaan ei tullu siihen mun kanssa istumaan, vaikka siinä ois paikka ollu. Kaikki meni pitkään pöytään ja siellä oli joku tuttu...Kukaan ei pubunu mitään, jos en minä menny sinne, niin kukaan ei tullu mun kanssa pubumaan...Koska ne meni kaikki siihen pitkään, ne oli kaikki vanhoja tuttuja. Se menee vaan näin.

Naiset analysoivat haastatteluissa toisten tapaa toimia, mutta arvioivat samalla myös itseään ja omaa käyttäytymistään, joskus hyvinkin kriittisesti. Sylvi pohti myös omaa rooliaan yksinäisyyden kannattelussa. Naiset haastoivat itseään siinä, olisivatko he voineet olla aktiivisempia ystävyyssuhteiden rakentamisessa ja hoidossa. Lisäksi he pohtivat, olivatko he itse valmiita sitoutumaan ystävyyteen. Aktiivisuutta ehkäisi osaltaan kokemus siitä, että monissa ryhmissä muille ryhmäläisille oli syntynyt jo oma piiri, johon ei tohdittu mennä mukaan. Uusien ystävyyssuhteiden rakentaminen vaatii myös voimia. Täytyy olla valmis jakamaan ajatuksiaan ja omia kokemuksiaan, eikä koskaan ihan varmasti tiedä mihin ja millaiseen ystävyyteen asiat johtavat. Naisten toiveena oli, että he voisivat olla enemmän ihmisten kanssa. Eräs haastateltava pohti sitä, jaksaako hän enää yrittää, koska ystävyys on aloitettava alusta. Yksinäisyyttä kokeva ihminen on herkkä aistimaan tilanteita, joissa ei saa vastavuoroisuutta ja kokee haavoittuvuutta. Osalle haastateltavista syntyi tunne siitä, että he joutuivat anelemaan etsiessään muiden seuraa ja tätä he eivät halunneet tehdä.
Sylvi: Se on niin kakspiippunen juttu, et kun sanotaan aina, et mene ja yksinkin voi mennä, mut siinä tulee paljon, mullekin on tullu semmosia mietteitä, että miks mun pitää kerjätä, jotenkin se masentaa - en mä osaa sitä oikein nyt pukee sanoiks. Mut sillai et, mikä mussa on vikana.

Haastateltavat eivät olleet löytäneet eläkkeelle jäätyään sosiaalista yhteisöä, johon he olisivat voineet kiinnittyä. He kaipasivat naisystävää, jonka kanssa voisi jakaa arjen asioita tai joka toimisi kannustajana ja innostajana. Kaisan sosiaalinen verkosto muodostui ainoastaan läheisistä perheenjäsenistä. Hän kaipasi ystävää, joka vetäisi häntä harrastusten pariin. Hän toivoi ystävältä kannustusta ja aktivointia, koska yksin hänellä ei tule lähdettyä kotoa mihinkään.

Kaisa: Niin, ja joku, joka vähä niinku kannustais ja tällä taval. Ettei ne oo aina jotenki, porukassa olkoon nyt yks tai useampi niin, joku sellanen. Hei, nyt lähetään ja nyt, olet sä valmis ja nyt mennään ja huomen on sit sitä ja tässä tällästä että... Etku ei oo sellasta siinä sitä toista niin, sit sitä vaan, byvin usein, niin no en mä nyt sit...En mä nyt sit lähekään.

Sylvin yksinäisyys poikkesi muiden naisten kokemuksista. Sylvin ystävät olivat muuton takia jääneet toiselle paikkakunnalle, ja hän tapasi heitä vain harvoin. Sylvi kaipasi itselleen sydänystävää, mitä toivetta hän oli kantanut läpi elämänsä. Hän toivoi löytävänsä ystävän, joka pitäisi hänestä aidosti eikä tyrmäisi häntä. Sylvin kohdalla yksinäisyys liittyi lapsuuden aikaisiin kokemuksiin ja niissä koettuihin pettymyksiin. Sylvin kokema yksinäisyys näyttäytyi haastattelujen valossa yksinäisyytenä, joka on ollut koko elämänkulkua läpäisevä teema. Hänellä yksinäisyys ei liittynyt vain tiettyihin elämässä tapahtuneisiin muutoksiin kuten eläkkeelle jääntiin. Myöhemmällä iällä koetun yksinäisyyden taustalla näkyvät erilaiset elämäntapahtumat. Niiden jäljet ovat joko olleet läsnä yksinäisyyden kokemuksena läpi 
elämän tai nousseet pintaan vasta myöhemmissä elämänvaiheissa, päättelee Tiilikainen (2016) tutkimuksessaan. Sylvin kohdalla kyse oli emotionaalisesta yksinäisyydestä (Weiss 1985), jota hän on kantanut mukanaan koko elämänsä ajan.

Sylvi: Kaipaan, joo. Ja, vielä kun ois joku semmonen kaveri kenen kanssa mä voisin mennä, lähetääs vaikka nyt yhdessä matkalle ja pakattais ja touhuttais yhdessä ja, mentäis yhdessä. Voiskos olla niin ihana, mut ilmeisesti mulla ei oo sitä koskaan, mä oon aina toivonu, et joku ottas mua kädestä kiinni ja mentäis ybdessä. Ja se välittäs musta ihan aidosti, et se tykkäis musta semmosena kun minä olen.

Laaditut verkostokartat olivat sosiaalisten suhteiden kuvauksia, jotka kertoivat sen hetkisestä tilanteesta. Haastateltavilla elämä oli aikaisemmin ollut kiireistä ja aikaa oli pitänyt jakaa perheen ja työn välillä. Iän myötä verkostot olivat supistuneet, mikä oli johtanut sosiaalisten suhteiden murentumiseen.

Haastatteluissa naisten yksinäisyyden kokemuksiin liittyi kaipuu ystävästä, jonka kanssa voisi puhua televisio-ohjelmista tai lehdestä luetuista asioista tai joka auttaisi päivittäisessä päätöksenteossa. Kaipauksessa oli kyse yhteisen arkitodellisuuden jakamisesta jonkun kanssa. Naiset kaipasivat aktivoijaa ja innostajaa, joka houkuttelee lähtemään harrastusten pariin tai jonka kanssa voisi jakaa ajatuksia ja mielipiteitä. Naisille merkityksellistä ystävyyssuhteissa oli yhteinen toiminta ja keskinäinen vuorovaikutus. Ystävyyteen kohdistetut odotukset ja toiveet eivät haastateltujen kohdalla kuitenkaan täyttyneet ja seurauksena oli saamattomuutta ja toivottomuutta.

\section{Hauras osallisuus}

Haastateltavat olivat harjaantuneet tulemaan toimeen pienellä budjetilla. Joustovaraa ei arjessa juurikaan ollut ja mahdolliset ylimääräiset menot oli karsittu minimiin. Suurimmalla osalla haastateltavista elokuvat, teatterit ja matkat olivat jääneet. Rahat riittivät perusmenoihin, kuten asumiseen, ruokaan ja lääkekuluihin.
Aino: Se on sikäli kaubeen yksinkertast, että oikeestaan [naurabtaa]. Ne rahat menee ihan tämmösiin perusasioibin. Siin oikeestaan ei oo mitään suunnittelemista. Se ei suunnitte- lemalla muutu ja mä oon sillain tarkka, et mä ostan tarjouksista ja en, mul ei oo mitään sel- lasia hukkaputkia et mul menis johonkin. En juo, en tupakoi, en [naurahtaa].

Arkeen kuului tarjousten seuraaminen, pakastamisen hyödyntäminen, tukiviidakossa suunnistaminen ja välillä tarvittiin myös aimo annos huumoria. Muutamalle pienen eläkkeen saajista taloudellista helpotusta toi parisuhde tai omien lasten tai sukulaisten tarjoama apu ja tuki. Aino kertoo, että ostaessaan ruokaa äidilleen tämän rahoilla, hän samalla ostaa jotain myös itselleen.

Aino: Tosi tiukkaa. Et kyllä, nyt kävin euronpäivillä, niin kyllä siellä monta tuotetta tuli ostettuu eurolla ja jotain vähä halvemmallaki. Siis tollast mitä nyt voi sit, jossaki, ruuan lisukkeeks laittaa ja tällasia juttuja. Leipää vähä pakkaseen. Mutta mun äiti siis, joka nyt on ollu eläkkeel jo iät ajat, niin se byvin paljo auttaa mua nois ruokahommis. Etku mä haen äidille ne tarvikkeet mitä se tarvii, niin sit mä siinä melkeen aina jotain ostan itelleniki. Ne menee sit sieltä äitin lompakosta. Et oon mä sitäki miettiny, et sit kun joskus, bän täältä maailmasta poistuu, niin sit mul on taas, iso lovi nois jutuis. Ku mul on kuitenki asunnostaki viel velkaa, mitä pitää maksaa joka kuukausi ja, noita kulutusluottoja ja tollasii on, että niitä joka, kuukausi menee jonkun verran.

Taloudesta kannettiin huolta ja siitä murehdittiin, koska haastateltavilta puuttui varmuus tulevasta. Ne haastateltavat, joilla oli taloudellisesti tiukkaa, mutta joilla ei vielä ollut suuria sairaus- tai lääkekuluja, murehtivat jo ennalta 
mahdollista sairastumistaan ja sen aiheuttamia taloudellisia seurauksia. Taloudellinen tiukkuus aiheutti huolen tulevaisuudesta ja siitä, miten pärjää, jos tulee yllättäviä menoja tai sairastuu. Tämä kosketti erityisesti yhden hengen taloudessa eläviä, jotka vastasivat yksin kaikista talouden menoista.

Sirkka: ...jos sairaaks romabtaa, niin romabtaa kyl talouskin. Lääkekulut mulla ei mitkään ihan hirveet oo vielä, mutta et just se, että niistä kun ei tiedä kasvaako ne vai ei.

Haastatteluissa yksinäisyyttä kuvattiin fyysisenä pahana olona: kurkkua kuristaa tai on iban semmonen olo et, ihan sisuskalutkin läbtee. Subjektiivisena kokemuksena yksinäisyys koettiin ahdistavana tunteena, mikä ilmeni fyysisenä pahana olona. Siihen liitettiin epämiellyttävyyden ja ahdistavuuden kokemuksia (Peplau \& Perlman 1982). Moni haastateltava oli joutunut karsimaan menoja, joiden avulla olisi ollut mahdollisuus kohdata samanhenkisiä ihmisiä ja löytää mielenkiintoista tekemistä. Jäljelle jäivät vain ilmaiset tilaisuudet, mikä kavensi mahdollisuuksia tavata muita samanikäisiä. Naiset pohtivat sitä, kuinka yhteys muuhun maailmaan oli heikentynyt murentuneiden sosiaalisten suhteiden vuoksi. Ahdistavien tunteiden yhdistyminen pienituloisuuteen aiheutti osalle haastateltavista ulkopuolisuuden kokemuksen.

Aino: Kyl silläkin on ihan selkeesti vaikutusta, koska sebän karsii ihan birveen ison osan pois. Kaikki mitä mä teen, niin on käytännös ilmaispalveluita. Joku, esimerkiks joogaa mä haluisin harrastaa. Mä oon joskus harrastanu, mutta sekin maksaa... Juu, vaikuttaa siis se, että jos ei mulla ois näitä naisten rybmiä, ni mähän kokisin itteni tavallaan ulkopuoliseks, ku sä et voi mitään harrastaa.

Taloudellinen tilanne rajoitti keinojen etsintää, joiden avulla olisi voinut löytää ulospääsyn tai ratkaisun yksinäisyyteen. Moni haasteltavista toivoi löytävänsä seuraa harrasteryhmistä.
Aino: Alotekykyä kaipaisin lisää ja sit varmaan se tulee ehkä sielt pohjalt myöskin - se semmonen merkityksettömyys, et asioil ei oo, ihan sama. Mitä sit, jos mä teen? Mitä välii?

Kynnys lähteä yksin harrastuksiin oli kuitenkin korkea. Naiset kertoivat aloitekyvyttömyydestä ja innostuksen puutteesta, jotka johtivat merkityksettömyyden tunteeseen. Asioilla ei ollut väliä, eikä syytä toimintaan löytynyt. Merkityksettömyyden kokemus syntyi, kun yhteys toisiin oli riittämätön. Niukkuudessa eläminen vie tulevaisuudenuskon ja elämästä tulee sinnittelyä (Isola ym. 2017).

Hilma: Sitä ei sanota ääneen, koska se on vaan semmonen tabu. Nii, et se koetaan sit niin negatiiviseks se myöntäminen et..

Yksinäisyyteen havahtumista kuvailtiin säälittäväksi oivallukseksi, johon oli totuttu, vaikka tilannetta ei pidetty tyydyttävänä. Hilma kuvaa edellisessä aineistokatkelmassa yksinäisyyden myöntämisen vaikeutta. Yksinäisyydestä ei puhuta ääneen, eikä siitä kerrota muille, koska yksinäisyys koetaan kielteisenä ja hävettävänä asiana, josta mielellään vaietaan (ks. Dahlberg 2007). Yksinäinen näkee itsensä usein huonompana kuin muut kanssaihmiset.

\section{Pohdinta}

Tässä tutkimuksessa tarkasteltiin 60-76-vuotiaiden pienituloisten naisten kokemaa yksinäisyyttä. Aineiston analysointi tuotti kolme pääteemaa: elämänkulun muutokset, murentuvat sosiaaliset suhteet ja hauraan osallisuuden. Elämänkulun muutosten osalta tutkimustulokset ovat samansuuntaisia aikaisempien tutkimusten kanssa (Aartsen \& Jylhä 2011; Beal 2009; Dykstra ym. 2005; Tiilikainen 2016). Tärkeitä yksinäisyyteen vaikuttavia elämänkulun muutoksia olivat eläkkeelle jäänti, muutto toiselle paikkakunnalle ja puolison kuolema. 
Naisilla yksinäisyyden kokemuksiin liittyi kielteisiä tunteita, jotka tuottivat ajoittain jopa fyysistä pahaa oloa. Yksinäisyyttä kuvattiin epämiellyttävänä ja ahdistavana kokemuksena (ks. Peplau ja Perlman 1982). Tutkimuksen tuloksissa läheisten merkitys kuuntelijana ja tuen antajana ei korostunut samalla tavoin kuin de Jong Gierveldin ja van Tilburgin (2010) tutkimuksessa. Naiset kertoivat sosiaalisesta yksinäisyydestä ja toiveista, joita kohdistettiin samanlaisessa elämäntilanteessa oleviin. Ikääntymisen myötä tapahtuva sosiaalisten suhteiden murentuminen kertoo siitä, kuinka vaikeaa on elämässä tapahtuneiden muutosten jälkeen solmia uusia ystävyyssuhteita. Yksinäisyyttä tutkineen Dahlbergin (2007) mukaan yksinäisyys auttaa ymmärtämään suhdetta maailmaan. Yksinäisyys etäännyttää ja jättää meidät ilman yhteyttä toisiin. Naisilla oli ystäviä ja läheisiä, mutta näistä sosiaalisista suhteista huolimatta, he kaipasivat samanhenkistä seuraa. Ystävyyteen kohdistetut odotukset ja toiveet eivät naisten kohdalla täyttyneet (vrt. de Jong Gierveld \& van Tilburg 2010).

Aiemmissa eläkeläisten toimeentuloon liittyvissä tutkimuksessa on havaittu, että osa eläkeläisistä joutuu pienituloisuuden takia tinkimään kulutuksestaan (Ahonen ym. 2017). Tutkimukseen osallistuneilla naisilla oli vaikeuksia tavanomaisten menojen kattamisessa ja taloudellinen tilanne rajoitti heidän toimintamahdollisuuksiaan. Subjektiivinen arvio taloudellisten resurssien riittävyydestä on todettu heijastuvan koettuihin sosiaalisiin suhteisiin ja laajemmin elämän tyytyväisyyteen (Palomäki 2009). Subjektiivinen kokemus pienituloisuudesta yhdistyneenä murentuneisiin sosiaalisiin suhteisiin tuottaa yksinäisyyden kokemuksia. Pienituloisilla eläkeläisillä tiukka taloudellinen tilanne heikentää toimintamahdollisuuksia ja rajoittaa vaihtoehtoisia tapoja etsiä ulospääsyä koetusta yksinäisyydestä. Iän karttuessa sairauskulut kasvavat, mikä yhdessä puutteellisen sosiaalisen tukiverkoston kanssa huolestuttaa jo ennalta.
On todettu, että hyvinvoinnin lähteet muodostuvat sekä aineellisista tekijöistä, kuten kohtuullisesta toimeentulosta että aineettomista lähteistä, kuten yhteenkuuluvuudesta ja osallisuudesta (Nussbaum 2011). Osallisuus ei kuitenkaan ole yksilöllinen ominaisuus, vaan kokemuksena se rakentuu vuorovaikutuksessa toisten ihmisten kanssa (Isola ym. 2017). Koetut pettymykset ystävyyssuhteiden rakentamisessa vaikuttavat itsearvostukseen ja tuottavat merkityksettömyyden kokemuksia. Naisten kohdalla sekä aineelliset että aineettomat hyvinvoinnin lähteet osoittautuivat puutteellisiksi.

Tutkimukseen osallistuneet naiset olivat osallistuneet ikääntyville naisille suunnattuun ryhmätoimintaan. Heillä oli siis kokemusta ryhmässä toimimisesta ja omista yksinäisyyden kokemuksista puhumisesta. Haastattelutilanteessa haastateltaville annettiin tilaa kertoa kokemuksistaan omin sanoin (ks. Aaltonen \& Leimumäki 2010). Haastattelut olivat ilmapiiriltään luottamuksellisia ja naiset puhuivat avoimesti sekä omasta pienituloisuudestaan että yksinäisyyteen liittyvistä henkilökohtaisista kokemuksistaan.

Ikääntyneiden yksinäisyyden ehkäisyyn ja lievittämiseen on etsitty erilaisia interventioita kuten teknologisia ja taidelähtöisiä ratkaisuja (Poscia ym. 2018). Tähän tutkimukseen osallistuneet naiset kaipasivat vuorovaikutuksellista toimintaa, jossa yhdistyy sekä mielekäs tekeminen että samassa tilanteessa olevien naisten kohtaaminen. Heille osallisuudessa oli kyse sekä toiminnasta että vuorovaikutuksesta ja yhteydestä toisiin. Yksinäisyyden lievittämiseen soveltuvia interventioita tutkittaessa hyödyllisiksi toimintatavoiksi ovat osoittautuneet ryhmäinterventiot (de Jong Gierveld 1998; Kangassalo \& Teeri 2017; Savikko ym. 2010; Pitkälä \& Routasalo 2012). Ryhmäinterventiot tarjoavat mahdollisuuden tarkastella itseä uudesta näkökulmasta ja saada tukea samassa tilanteessa olevilta ikääntyviltä. Vertaisuus samanlaisia kokemuksia omaavien kanssa tuo elämään merkityksellisyyttä ja auttaa löytä- 
mään uusia voimaannuttavia polkuja kohti osallisuutta. Tutkimustulokset osoittavat, että ryhmäinterventioita kehitettäessä tulee kiinnittää erityistä huomiota ryhmän keskinäiseen ilmapiiriin, jotta kaikki ryhmäläiset kokevat itsensä tervetulleiksi. Tutkimuksen tuloksia voidaan hyödyntää uusien interventioiden kehittämisessä, jotka edistävät sosiaalista osallisuut- ta ja huomioivat ikääntyvien naisten tarpeet ja pienituloisuuden aiheuttamat rajoitukset.

\section{Yhteydenotto \\ Anne Rahikka, VTT \\ Miina Sillanpään Säätiö \\ anne.rahikka@miinasillanpaa.fi}

\section{Kirjallisuus}

Aaltonen, T. \& Leimumäki, A. (2010). Kokemus ja kerronnallisuus - kaksi luentaa. Teoksessa Ruusuvuori, J., Nikander, P. \& Hyvärinen, M. (toim.) Haastattelun analyysi. Tampere: Vastapaino 119152.

Aartsen, M. \& Jylhä, M. (2011). Onset of loneliness in older adults: results of a 28 year prospective study. European Journal of Ageing, 8 (1), 31-38.

Ahonen, K., Palomäki, L-M. \& Polvinen, A. (2017). Eläkeläisten toimeentulokokemukset vuonna 2017. Eläketurvakeskus. Haettu 14.12.2018 osoitteesta: https://www.slideshare.net/Elaketurvakeskus/elkelisten-toimeentulokokemukset-vuonna-2017.

Beal, C. (2009). Loneliness in older women: A review of the literature. Issues in Mental Health Nursing, 27 (7), 795-813. https://doi.org/10.1080/01612840600781196.

Borys, S. \& Perlman, D. (1985). Gender differences in loneliness. Personality and Social Psychology Bulletin, 11 (1). https://doi.org/10.1177\%2F0146167285111006

Dahlberg, K. (2007). The enigmatic phenomenon of loneliness. International Journal of Qualitative Studies on Health and Well-being, 2 (4), 195-207.

Dahlberg, L. \& McKee, K. J. (2014). Correlates of social and emotional loneliness in older people: evidence from an English community study. Aging E' Mental Health, 18, 504-514.

Dykstra, P.A., van Tilburg, T. G. \& de Jong Gierveld, J. (2005). Changes in Older Adult Loneliness. Results from a seven-year longitudinal study. Research on Aging, 27 (6), 725-747. https://doi.org/10.1177/0164027505279712.

Hannikainen, K. (2019). Ikääntyneiden sosiaali- ja terveyspalveluiden tarve ja käyttö tulotason mukaan. Teoksessa Kestilä,L. \& Karvonen, S. (toim.) Suomalaisten hyvinvointi 2018 (s. 265-278). Terveyden ja hyvinvoinnin laitos.
Heikkinen, R-K. (2013). Sosiaalinen toimintakyky ja sen arviointikeinot. Gerontologia 27 (4), 386-396.

Hirsjärvi, S. \& Hurme, H. (2008). Tutkimushaastattelu: Teemahaastattelun teoria ja käytäntö. Helsinki: Gaudeamus.

Hirvilammi, T. (2015). Kestävän hyvinvoinnin jäljillä. Ekologisten kysymysten integroiminen byvinvointitutkimukseen. Sosiaali- ja terveysturvan tutkimuksia 136. Helsinki: Kelan tutkimusosasto.

Honigh-de Vlaming, R., Haveman-Nies, A., Heinrich, J., van't Veer, P. \& de Groot, L. (2013). Effect evaluation of a two-year complex intervention to reduce loneliness in non-institutionalised elderly Dutch people. BMC Public Health, 13 (984), 1-13.

Isola, A-M., Kaartinen, H., Leemann, L., Lääperi, R., Schneider, T., Valtari, S. \& Keto-Tokoi, A. (2017). Mitä osallisuus on? Osallisuuden viitekehystä rakentamassa. Työpaperi 22/2017. Terveyden ja hyvinvoinnin laitos. Haettu 21.1.2019 osoitteesta: http://www.julkari.fi/handle/10024/135356.

Jong Gierveld, J. de \& van Tilburg, T. (2010). The De Jong Gierveld short scales for emotional and social loneliness: tested on data from 7 countries in the UN generations and gender surveys. European Journal of Ageing, 7 (2), 121-130.

Jong Gierveld, J. de (1998). A review of loneliness: concept and definitions, determinants and consequences. Reviews in Clinical Gerontology, 8 (1), 73-80.

Kangassalo, R. \& Teeri, S. (2017). Yksinäisyys kotona asuvien iäkkäiden elämässä. Gerontologia, 31 (4), 278-290.

Karisto, A. \& Tiilikainen, E. (2017). Yksinäisyys ja aika. Yhteiskuntapolitiikka 82 (5), 527-537.

Krippendorff, K. (1990). Content analysis; An Introduction to Its Methodology. Newbury Park: Sage. 
Liu, L., Gou, Z. \& Zuo, J. (2016). Social support mediates loneliness and depression in elderly people. Journal of Health Psychology, 21 (5), 750-758.

Liukko, J. \& Mustonen, C. (2019). ”Aina kun poistut kotoa se maksaa!" Eläkeläisten koettua toimeentuloa vaikeuttavat ja helpottavat tekijät avovastausten perusteella. Teoksessa Ahonen, K., Nivalainen, S., Palomäki, L-M., \& Polvinen, A. (toim.) Tutkimuksia eläkeläisten toimeentulokokemuksista ja taloudellisesta byvinvoinnista (s. 185-211). Eläketurvakeskuksen tutkimuksia 02/2019. Helsinki: Eläketurvakeskus.

Martina, C., Stevens, N. \& Westerhof, G. (2018). Change and stability in loneliness and friendship after an intervention for older women. Ageing and Society, 38 (3), 435-454.

Moisio, P. \& Rämö, T. (2007). Koettu yksinäisyys demografisten ja sosioekonomisten taustatekijöiden mukaan Suomessa vuosina 1994 ja 2006. Yhteiskuntapolitiikka 72 (4), 392-401.

Mullainathan, S. \& Shafir, E. (2013). Scarcity: why having too little means so much. New York: Times Books, Henry Holt and Company.

Nussbaum, M. (2011). Creating capabilities: The human development approach. Cambridge: Belknap Press of Harvard University Press.

Nyman, H., Karjalainen, T. \& Pösö, R. (toim.). Tilasto Suomen eläkkeensaajista 2017. Eläketurvakeskuksen tilastoja 10/2018. Helsinki: Eläketurvakeskus. Haettu 10.3.2019 osoitteesta: https://www.etk.fi/ julkaisu/tilasto-suomen-elakkeensaajista/.

Ojala, H. (2010). Opiskelemassa tavallaan. Vanhat naiset ikäihmisten yliopistossa. Akateeminen väitöskirja. Tampereen yliopisto, Kasvatustieteiden tiedekunta. Haettu 11.3.2019 osoitteesta http://tampub.uta.fi/bitstream/handle/10024/66690/978-951-44-8298-4.pdf?sequence $=1 \&$ isAllowed $=\mathrm{y}$.

Palomäki, L-M. (2009). Mitkä tekijät selittävät pienituloisten eläkeläisten toimeentulokokemusten eroja? Yhteiskuntapolitiikka 74 (5), 542-553.

Peplau, L. \& Perlman, D. (1982). Perspectives on loneliness. Teoksessa Peplau, L. \& Perlman, D. (toim.) Loneliness: A sourcebook of current theory, research and therapy (s. 1-18). New York: A Wiley-Interscience publication.

Pinquart, M. \& Sörensen, S. (2001). Influences on loneliness in older adults: A meta-analysis. Basic and applied social psychology, 23 (4), 245-266.
Pitkälä, K. \& Routasalo, P. (2012). Ryhmästä apua vanhusten yksinäisyyteen. Lääketieteellinen Aikakauskirja Duodecim, 128 (12), 1215-1216.

Poscia, A., Stojanovic, J., Ignazio La Milia, D., Duplaga, M., Grysztar, M., Moscato, U., Onder, G., Collamati, A., Ricciardi, W. \& Magnavita, N. (2018). Interventions targeting loneliness and social isolation among the older people: An update systematic review. Experimental Gerontology. 102,133-144.

https://doi.org/10.1016/j.exger.2017.11.017.

Russell, D., Peplau, L. A., \& Cutrona C. E. (1980). The revised UCLA Loneliness Scale: concurrent and discriminant validity evidence. Journal of Personality and Social Psychology, 39 (3), 472-480.

Ruusuvuori, J., Nikander, P. \& Hyvärinen, M. (2010). Haastattelun analyysin vaiheet. Teoksessa Ruusuvuori, J., Nikander, P. \& Hyvärinen, M. (toim.) Haastattelun analyysi (s. 9-36). Tampere: Vastapaino.

Savikko, N., Routasalo, P., Tilvis, R. \& Pitkälä, K. (2010). Psychosocial group rehabilitation for lonely older people: favourable processes and mediating factors of the intervention leading to alleviated loneliness. International Journal of Older People Nursing, 5, 16-24.

Seikkula, J. (1994). Sosiaaliset verkostot - ammattiauttajan voimavara kriiseissä. Helsinki: Kirjayhtymä.

Thernborn, G. (2014). Eriarvoisuus tappaa. Tampere: Vastapaino.

Tiilikainen, E. (2016). Yksinäisyys ja elämänkulku. Laadullinen seurantatutkimus ikääntyvien yksinäisyydestä. Akateeminen väitöskirja. Helsingin yliopisto, Valtiotieteellisen tiedekunnan julkaisuja 4 (2016). Haettu 15.5.2018 osoitteesta: https://helda.helsinki.fi/handle/10138/161065.

Tuomi,J. \& Sarajärvi, A. (2018). Laadullinen tutkimus ja sisällönanalyysi. Helsinki: Tammi.

Uotila, H. (2011). Vanhuus ja yksinäisyys. Tutkimus iäkkäiden ibmisten yksinäisyyskokemuksista, niiden merkityksistä ja tulkinnoista. Akateeminen väitöskirja. Acta Universitatis Tamperensis 1651. Haettu 11.11.2018 osoitteesta: http://urn.fi/urn:isbn:978-951-44-8553-4.

Vaarama, M., Mukkila, S. \& Hannikainen-Ingman, K. (2014). 80 vuotta täyttäneiden elämänlaatu ja elinolot. Teoksessa Vaarama, M., Karvonen, S., Kestilä, L., Moisio, P. \& Muuri, A. (toim.) Suomalaisten byvinvointi 2014 (s. 40-60). Helsinki: Terveyden ja hyvinvoinnin laitos. 
Victor, C. R., \& Bowling, A. (2012). A Longitudi- $\quad$ Yang, Y., Boen, C., Gerken, K., Li, T., Schorpp, K. nal Analysis of loneliness among older people in Great Britain. The Journal of Psychology, 146(3), 313-331. https://doi.org/10.1080/00223980.2011.609572.

Weiss, R. (1985). Loneliness: The Experience of Emotional and Social Isolation. Cambridge: The MIT Press. \& Harris, K. (2016). Social relationships and physiological determinants of longevity across the human life span. PNAS, 113 (3), 578-583. https://doi.org/10.1073/pnas.1511085112. 